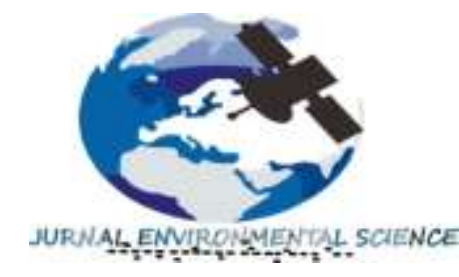

Jurnal Environmental Science

Volume 4 Nomor 1 Oktober 2021

p-ISSN : 2654-4490 dan e-ISSN : 2654-9085

Homepage at : ojs.unm.ac.id/JES

E-mail:jes@unm.ac.id

\title{
ANALISIS SUHU PERMUKAAN KOTA MAKASSAR SEBELUM DAN SELAMA MASA PANDEMI COVID-19
}

\author{
Ramli Umar ${ }^{1}$, Muhammad Rais Abidin², Rizal Darwis ${ }^{3}$, Rahmi Nur ${ }^{4}$, Andi Arham \\ Atjo $^{5}$, Dinil Qaiyimah ${ }^{6}$, Syamsunardi $^{7}$, Jeddah Yanti ${ }^{8}$ \\ 1,2,3,6,7,8 Jurusan Geografi, Universitas Negeri Makassar \\ 4,5 Jurusan Ilmu Kelautan, Universitas Negeri Sulawesi Barat \\ e-mail:*muhraisabidin@gmail.com
}

\begin{abstract}
Since the first confirmed case of Covid-19 infection in March 2020 in Indonesia, various programs have been followed to break the chain of distribution, such as the Large-Scale Social Restrictions which directly limit the activities and mobility of the community, resulting in a decrease in transportation, trade and service activities. , as well as education and have implications for reducing air pollution. Therefore, this study aims to see how the surface temperature in Makassar City before and during the Covid-19 pandemic. The data used is Landsat 8 OLI TRS. The results showed that before and during the Covid-19 pandemic the average surface temperature in Makassar City decreased by around $2.3^{\circ} \mathrm{C}$.
\end{abstract}

Keywords: Surface Temperature, Covid-19

\begin{abstract}
ABSTRAK
Sejak kasus infeksi Covid-19 pertama kali terkonfirmasi pada bulan Maret 2020 di Indonesia dengan diikuti berbagai macam program dalam memutus mata rantai penyeberan seperti Pembatasan Sosial Berskala Besar (PSBB) yang secara langsung membatasi aktifitas dan mobilitas masyarakat yang berakibat penuruan aktifitas transportasi, perdagangan dan jasa, serta pendidikan dan berimplikasi terhadap penurunan polusi udara. Oleh karena itu, penelitian ini bertujuan untuk melihat bagaimana suhu permukaan di Kota Makassar sebelum dan selama pandemi Covid 19. Data yang digunakan adalah Landsat 8 OLI TRS. Hasil penelitian menunjukkan bahwa sebelum dan selama masa pandemi Covid-19 rata-rata suhu permukaan di Kota Makassar mengalami penurunan sekitar $2.3{ }^{\circ} \mathrm{C}$.
\end{abstract}

Kata Kunci: Suhu Permukaan, Covid-19 


\section{PENDAHULUAN}

Perkembangan aktifitas perkotaan secara langsung berpengaruh terhadap peningkatan polusi yang berakibat pada naiknya suhu permukaan. Kota Makassar yang merupakan salah satu kota metropolitan terbesar di Indonesia tak luput dari perkembangan aktifitas perkotaan khususnya peningkatan kawasan pemukiman dimana dalam kurun waktu 4 tahun telah terjadi peningkatan kawasan pemukiman sebesar 8.6\% (Abidin et al, 2019). Peningkatan kawasan pemukiman dipengaruhi oleh laju pertumbuhan penduduk yang tinggi (Ali et al, 2019) yang juga berdampak pada peningkatan kemacetan (Ali et al, 2017). Akibat tingginya laju perkembangan kawasan perkotaan dimana pada tahun 2019 tercatat suhu permukaan Kota Makassar sekitar $25-33^{\circ} \mathrm{C}$ (Abidin et al, 2021). Akan tetapi sejak merebaknya pandemic virus Corona (Covid-19) yang kasus pertama tercatat di Wuhan, Provinsi Hubei China kemudian menyebar ke lebih dari 219 negara sampai hari ini. Secara global sampai pada Agusutus 2021 tercatat terdapat 203 juta orang telah terinfeksi dan 4.3 juta meninggal (https://www.worldometers.info/coronavirus/).

Sementara di Indonesia kasus infeksi Covid-19 pertama terjadi pada bulan maret 2020 dan telah menyebar sangat cepat ke hampir semua pulau di Indonesia tak terkecuali Kota Makassar dengan jumlah kasus terinfeksi 3.64 juta (https://infeksiemerging.kemkes.go.id/dashboard/covid-19). Ditengah peningkatan kasus yang sangat tinggi, pada April 2020 pemerintah pusat dan pemerintah Kota Makassar khususnya mengambil langkah melakukan Pembatasan Sosial Berskala Besar (PSBB) guna memutus mata rantai persebaran Covid-19 kemudian memasuki satu tahun lebih sejak kasus pertama di Indonesia pemerintah kembali mengambil tindakan pencegahan ditengah meningkatnya kasus dan munculnya varian baru dengan menerapkan Pemberlakuan Pembatasan Kegaitan Masyarakat (PPKM). Kedua program tersebut secara signifikan menurunkan aktifitas dan mobilitas masyarakat. Menurut Covid-19 Community Mobility Report oleh Google menunjukkan terjadi penurunan mobilitas masyarakat di Kota Makassar yang terdiri atas perdagangan dan rekreasi sebesar $7 \%$, aktifitas di tempat kerja $27 \%$ dan transportasi baik transportasi umum maupun pribadi sebesar $48 \%$.

Sejak penerapan program PSBB maupun PPKM selama masa pandemi Covid-19 secara langsung membatasi aktifitas dan pergerakan masyarakat sehingga terjadi penurunan tingkat polusi yang berdampak pada menurunnya suhu permukaan (Muhammad et al, 2020) seperti terjadi di Kota Jakarta dan Surabaya (Wijayanto et al, 2020). Kota Makassar yang juga menjadi salah satu kota besar yang menerapkan kedua program tersebut diyakini telah mengalami penurunan tingkat polusi yang sangat signifikan. Oleh karena itu, penelitian ini bertujuan untuk melakukan analisis suhu permukaan di wilayah administratif Kota Makassar guna melihat apakah selama pandemi Covid-19 terjadi penurunan suhu permukaan.

\section{METODE PENELITIAN}

Lokasi penelitian ini berada di wilayah administratif Kota Makassar. Pemilihan lokasi penelitian ini didasarkan karena Makassar adalah salah satu kota metropolitan dan merupakan kota terbesar yang ada di Indonesia timur dengan jumlah penduduk tahun 2021 sebanyak 1.4 
juta jiwa (BPS, 2021) yang dikeliling beberapa kota-kota kecil seperti Kabupaten Gowa, Maros dan Takalar. Kondisi suhu permukaan sangat bervariasi mulai dari $25.1^{\circ} \mathrm{C}$ (Bulan Februari) sampai $28.2^{\circ} \mathrm{C}$ (Bulan September) dengan suhu rata-rata $28.45^{\circ} \mathrm{C}$. Lokasi penelitian dapat dilihat pada gambar 1 .

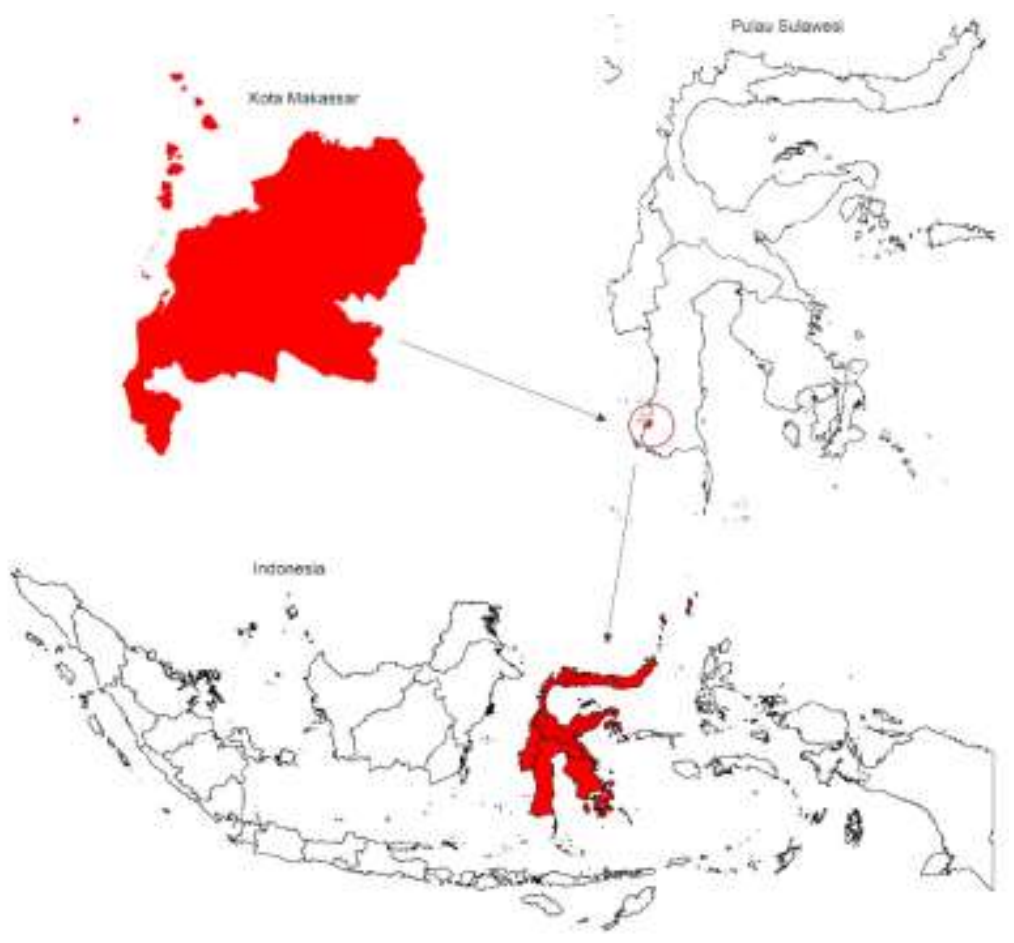

Gambar 1. Lokasi Penelitian

Penelitian ini menggunakan data Landsat 8 OLI TIRS dengan resolusi spasial $30 \mathrm{~m}$ yang dapat diakses melalui portal website USGS Earth Explorer (https://earthexplorer.usgs.gov/) dengan perekaman data dilakukan pada bulan September 2018 (sebelum pandemic Covid-19) dan pada bulan Agustus 2020 (masa pandemic Covid-19). Proses analisis data dimulai dengan mendaptkan spectral radiance (L $\lambda$ ) dengan persamaan:

$$
L_{\lambda}=M_{\mathrm{B} 10} Q_{\mathrm{cal}}+A_{\mathrm{L}}
$$

Setelah di dapatkan nilai spectral radiance (L $\lambda)$, maka tahapan selanjutnya adalah melakukan konversi nilai spectral radiance (L $\lambda)$ menjadi nilai spectral reflectance $\left(R_{\lambda}\right)$ dengan persamaan:

$$
R_{\lambda}=\left(M_{\rho} Q_{\mathrm{cal}}+A_{\rho}\right) / \sin \left(\theta_{\mathrm{SE}}\right)
$$

Kemudian dilakukan konversi nilai spectral reflectance $\left(R_{\lambda}\right)$ menjadi nilai brightness temperature dengan persamaan:

$$
\tau_{\mathrm{se}}=\frac{K_{3}}{\ln \left(\frac{K_{1}}{L_{\mathrm{e}}}\right)+1}
$$

Selanjutnya menghitung nilai vegetasi dan emisi dengan persamaan: 
Nilai vegetasi

$$
\mathrm{NDVI}-\frac{\left(\mathrm{NIK}_{\mathrm{s}}-\mathrm{Ked}_{54}\right)}{\left(\mathrm{NIR}_{\mathrm{H}}+\mathrm{Red}_{44}\right)}
$$

Nilai emisi

$$
p_{v}=\left(\frac{\mathrm{NDVI}-\mathrm{NDVI}_{\mathrm{s}}}{\mathrm{NDVI}_{\mathrm{v}}-\mathrm{NDVI}_{\mathrm{S}}}\right)^{2}
$$

Tahapan terakhir adalah menghitung suhu permukaan (Land surface temperature) dengan persamaan:

$$
\operatorname{LST}\left({ }^{\circ} \mathrm{C}\right)=\frac{T_{\mathrm{se}}}{\left[1+\left(i \times\left(\frac{T_{m}}{\rho}\right)\right) \times \ln \left(\varepsilon_{\operatorname{mos}}\right)\right]^{-273.15}}
$$

\section{HASIL DAN PEMBAHASAN}

\section{Hasil}

Penelitian ini membandingkan LST (Land Surface Temperature) atau suhu permukaan antara sebelum dan selama masa pandemi Covid-19 di Kota Makassar. Citra Satelit yang digunakan adalah Landsat 8 OLI TIRS dengan tutupan awan paling minimum. Data citra yang digunakan untuk merepresentasikan kondisi sebelum pandemi Covid-19 dengan tutupan awan (cloud cover) paling minimum yaitu pada tanggal 16 September 2018, sedangkan data citra yang paling minimum awan untuk merepresentasikan kondisi selama masa pandemi Covid-19 yaitu pada tanggal 20 Agustus 2020. Adapun data citra Landsat 8 OLI TIRS dapat dilihat pada tabel 1 dan gambar 2.

Tabel 1. Nilai Minimal, Nilai Maksimal dan Nilai Rata-Rata Suhu Permukaan Kota Makassar Sebelum dan Selama Pandemi Covid-19

\begin{tabular}{|c|c|c|c|c|}
\hline Keterangan & $\begin{array}{c}\text { Waktu } \\
\text { Perekaman } \\
\text { Citra }\end{array}$ & $\begin{array}{c}\text { LST Minimum } \\
\left({ }^{\circ} \mathrm{C}\right)\end{array}$ & $\begin{array}{c}\text { LST Maksium } \\
\left({ }^{\circ} \mathrm{C}\right)\end{array}$ & $\begin{array}{c}\text { LST Rata-Rata } \\
\left({ }^{\circ} \mathrm{C}\right)\end{array}$ \\
\hline $\begin{array}{c}\text { Sebelum } \\
\text { Pandemi } \\
\text { Covid-19 }\end{array}$ & $\begin{array}{c}16 \text { September } \\
2018\end{array}$ & 19.36 & 39.93 & 29.64 \\
\hline $\begin{array}{c}\text { Selama } \\
\text { Pandemi } \\
\text { Covid-19 }\end{array}$ & $\begin{array}{c}20 \text { Agustus } \\
2020\end{array}$ & 20.05 & 37.68 & 28.85 \\
\hline
\end{tabular}

Sumber: Hasil Analisis Landsat 8 OLI TIRS 


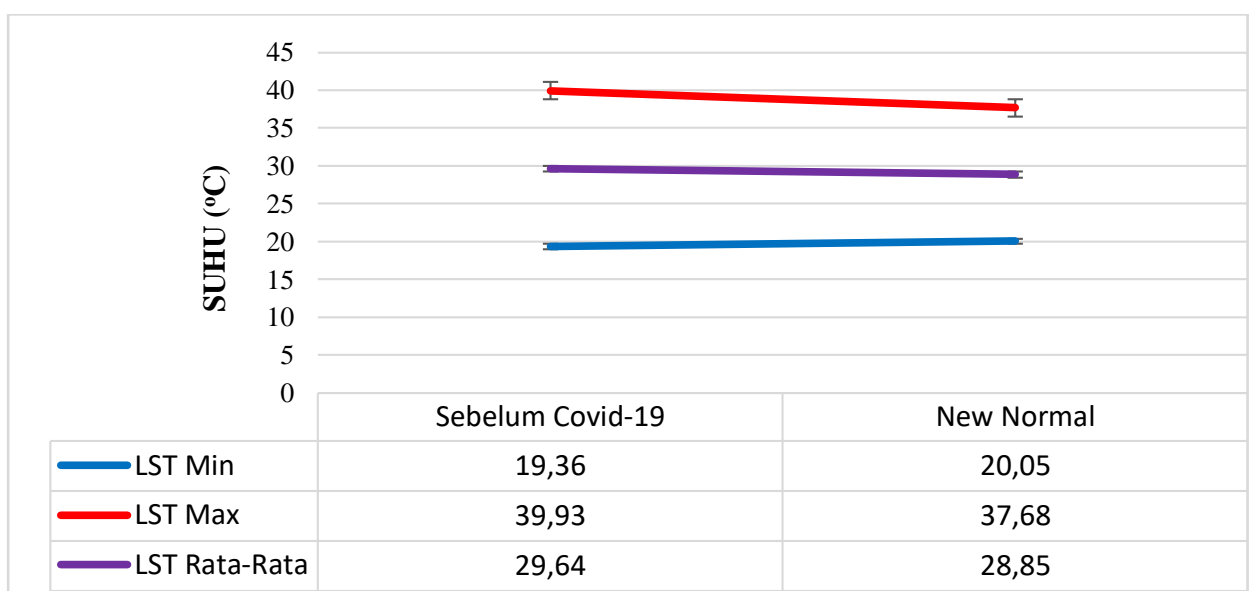

Gambar 2. Grafik Perbandingan Nilai Temperature Permukaan Kota Makassar Sebelum dan Selama Pandemi Covid-19

Berdasarkan Tabel 1 dan Gambar 2 menunjukan perbandingan nilai LST (Land Surface Temperature) di Kota Makassar sebelum dan selama masa pandemi Covid-19 memliki perbedaan rata-rata yang tidak terlalu signifikan dimana suhu rata-rata permukaan pada perekaman citra tanggal 16 September 2018 (sebelum masa pandemi Covid-19) adalah $29.64{ }^{\circ} \mathrm{C}$, sedangkan perekaman citra pada tanggal 20 Agustus 2020 (selama masa pandemi) memiliki suhu rata-rata yaitu $28.85^{\circ} \mathrm{C}$.

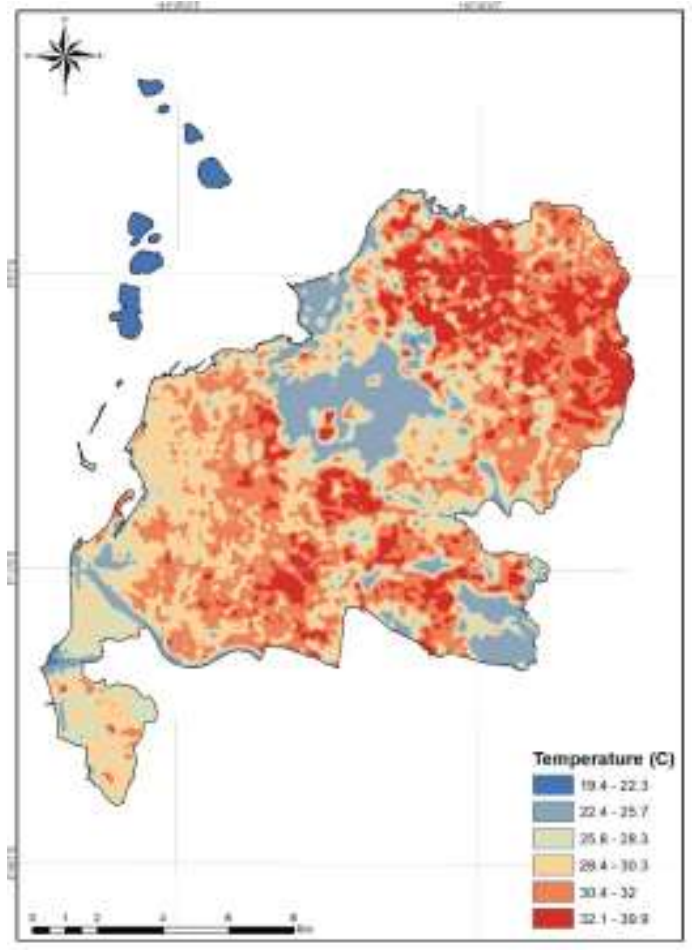

Land Surface Temperature Tahun 2018

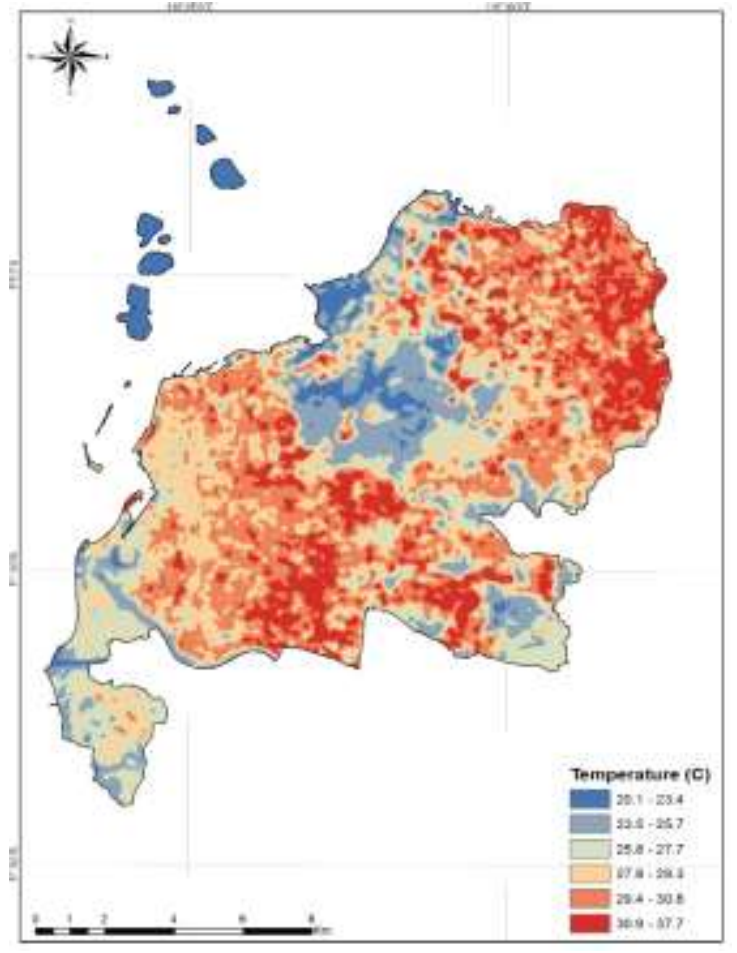

Land Surface Temperature Tahun 2020

Gambar 3. Hasil Analisis Suhu Permukaan dan Perbandingan Nilai Suhu Permukaan Kota Makassar Sebelum dan Selama Masa Pandemi Covid-19

Berdasarkan Gambar 3 menunjukkan bahwa pandemi Covid-19 memberikan pengaruh yang besar terhadap kondisi suhu permukaan yang mana dapat dilihat pada tahun 2018 
sebelum pandemi Covid-19, suhu permukaan paling tinggi di Kota Makassar adalah $39.9{ }^{\circ} \mathrm{C}$, sedangkan pada tahun 2020 atau selama masa pandemi Covid-19 suhu permukaan paling tinggi di Kota Makassar adalah $37.6{ }^{\circ} \mathrm{C}$ yang berarti sebelum dan selama masa pandemi terjadi penurunan suhu permukaan sebesar $2.3{ }^{\circ} \mathrm{C}$.

\section{Pembahasan}

Berdasarkan hasil penelitian menunjukkan bahwa sebelum dan selama masa pandemi Covid-19 rata-rata suhu permukaan di Kota Makassar mengalami penurunan sekitar $2.3{ }^{\circ} \mathrm{C}$ dimana hal ini juga terjadi di kota-kota besar dunia lainya yang terkena dampak seperti Wuhan, China (Hadibasyir et al, 2020), Delhi (Nanda et al, 2020), Raipur City (Guha et al, 2021), Dehradun City (Maithani et al, 2020) Kolkata City, India (Sahani et al, 2021), Jakarta and Surabaya Indonesia (Wijayanto et al, 2020). Salah satu faktor yang menjadi penyebab utama penurunan suhu permukaan sebelum dan selama pandemi Covid-19 adalah berkurangnya aktifitas manusia seperti kebijakan bekerja dan belajar dari rumah, penutupan pusat-pusat keramaian dan pusat perbelanjaan, pembatasan pada angkutan umum dan pribadi baik angkutan darat, udara dan laut dan pengurangan jam operasional dan tenaga kerja industri-industri yang berdampak pada pengurangan produksi, hal itu terlihat dari data Covid19 Community Mobility Report oleh Google menunjukkan terjadi penurunan mobilitas masyarakat di Kota Makassar yang terdiri atas perdagangan dan rekreasi sebesar 7\%, aktifitas di tempat kerja $27 \%$ dan transportasi baik transportasi umum maupun pribadi sebesar $48 \%$. Sebaliknya peningkatan trend suhu permukaan Kota Makassar sebelum pandemi Covid-19 diakibatkan penurunan kawasan terbuka hijau (Abidin et al, 2021) dan kawasan perairan darat perkotaan (Ali et al, 2019).

\section{SIMPULAN}

Penurunan aktifitas manusia selama masa pandemi Covid-19 secara langsung mengurangi Suhu Permukaan (Land Surface Temperature) di Kota Makassar hal ini dikarenakan adanya penurunan aktifitas dan pergerakan manusia seperti kebijakan bekerja dan belajar dari rumah, penutupan pusat-pusat keramaian dan pusat perbelanjaan, pembatasan pada angkutan umum dan pribadi baik angkutan darat, udara dan laut dan pengurangan jam operasional dan tenaga kerja industri-industri yang berdampak pada pengurangan produksi.

\section{DAFTAR RUJUKAN}

Ali, Muhammad Ichsan and Abidin, Muhammad Rais (2018) Population Density and Intensity of Traffic Connection: Spatial Analysis (Overlay). International Journal of Science and Research (IJSR), 7 (12). pp. 546-552. ISSN 2319-7064

Ali, Muhammad Ichsan and Dirawan, Gufran Darma and Hasim, Abdul Hafid and Abidin, Muh Rais (2019) Detection of Changes in Surface Water Bodies Urban Area with NDWI and MNDWI Methods. International Journal on Advanced Science Engineering Information Technology, 9 (3). pp. 946-951. ISSN 2088-5334.

Ali, Muhammad Ichsan and Hasim, A. Hafid and Abidin, M. Raiz (2019) Monitoring the Built-up Area Transformation Using Urban Index and Normalized Difference Built-up Index Analysis. International Journal of Engineering Transactions B: Applications, 32 (5). pp. 647-653. ISSN 1735-9244. 
Badan Pusat Statistik. Makassar Dalam Angka 2021 https://makassarkota.bps.go.id/publication/2021/02/26/be312e3f776bcfd005978bda/ko ta-makassar-dalam-angka-2021.html.

Covid-19 Community Mobility Report https://www.google.com/covid19/mobility/

Covid-19 Coronavirus Pandemic https://www.worldometers.info/coronavirus

Hadibasyir, H., Z, Rijal, S., S, \& Sari, D., R. Comparison of Land Surface Temperature during and Before the Emergence of Covid-19 Using Modis Imagery in Wuhan City, China. Forum Geografi, Vol 34 (1) July 2020: 1-15. DOI: 10.23917/forgeo.v34i1.10862.

Maithani, S., Nautiyal, G. \& Sharma, A. Investigating the Effect of Lockdown During COVID-19 on Land Surface Temperature: Study of Dehradun City, India. J Indian Soc Remote Sens 48, 1297-1311 (2020). https://doi.org/10.1007/s12524-020-01157-w

M. R. Abidin and A. Arfan, "Detection of Development and Density Urban Build-Up Area with Satellite Image Overlay", Int. J. Environ. Eng. Educ., vol. 1, no. 2, pp. 40-45, Aug. 2019.

M. R. Abidin, R. Nur, E. M. Mayzarah, and R. Umar, "Estimating and Monitoring the Land Surface Temperature (LST) Using Landsat OLI 8 TIRS”, Int. J. Environ. Eng. Educ., vol. 3, no. 1, pp. 17-24, Apr. 2021.

Muhammad, S., Long, X., Salman, M., 2020. COVID-19 pandemic and environmental pollution: a blessing in disguise? Science of the Total Environment 728:138820.

Nanda, D., Mishra, D., R, Swain, D., COVID-19 lockdowns induced land surface temperature variability in mega urban agglomerations in India. Environ.Sci.Processes Impact, 2021, 23, 144-159. https://doi.org/10.1039/D0EM00358A

Sahani, N., Goswami, S.K. \& Saha, A. The impact of COVID-19 induced lockdown on the changes of air quality and land surface temperature in Kolkata city, India. Spat. Inf. Res. 29, 519-534 (2021). https://doi.org/10.1007/s41324-020-00372-4

Subhanil Guha \& Himanshu Govil (2021) COVID-19 lockdown effect on land surface temperature and normalized difference vegetation index, Geomatics, Natural Hazards and Risk, 12:1, 1082-1100, DOI: 10.1080/19475705.2021.1914197

USGS Earth Explorer EarthExplorer (usgs.gov)

Wijayanto, Arif \& Rushayati, Siti \& Hermawan, Rachmad \& Setiawan, Yudi \& Prasetyo, Lilik. (2020). Jakarta and Surabaya land surface temperature before and during the Covid-19 pandemic. 12. 213-221. 